\title{
Dissipation of Thiobencarb Concentration in Soil Solution under an Upland Field Condition and Its Herbicidal Activity*
}

\author{
Yasuhiro Yogo**, Do-Jin Lee***, Katsuichiro Kobayashi*** and Hirosi Sugiyama**
}

\begin{abstract}
An emulsifiable concentrate of thiobencarb, $S$-(4-chlorobenzyl) diethylthiocarbamate (active ingredient : 50\%, Saturn ${ }^{\circledR}$ ), was applied at $15 \mathrm{~kg}$ a.i./ha to an upland field just after sorghum (Sorghum bicolor) sowing. Thiobencarb concentration in soil solution and centrifuged soil began to decrease 7 days after application (DAA) in 0$5 \mathrm{~cm}$ from the soil surface. The ratio of thiobencarb concentration between the soil solution and the centrifuged soil was about $2 \%$ at 0 DAA and decreased to ca. $0.4 \%$ at 11 DAA. Sorghum growth was suppressed within 2 weeks in the field. In the laboratory, sorghum sensitivity to thiobencarb was closely related to the initial concentration in the soil solution of $0-1 \mathrm{~cm}$ from the soil surface, in which most thiobencarb was distributed. Consequently, it was supposed that herbicidal activity of soil-applied thiobencarb on sorghum was largely dominated by the initial concentration in soil solution in the soil surface under an upland field condition.
\end{abstract}

Key words : thiobencarb, soil solution, upland field condition, herbicidal activity

* A part of this study was presented at the 34th Annual Meeting of the Weed Science of Japan in April, 1995.

** National Agricultural Research Center (NARC), Tsukuba, Ibaraki 305, Japan.

*** Institute of Applied Biochemistry, University of Tsukuba, Ibaraki 305, Japan.

(Received July 13, 1995)

\section{Introduction}

Numerous laboratory and field studies on herbicides in soil solution have been reported under upland conditions. Laboratory studies $^{1 \sim 3,6,10,13,14)}$ have focused on adsorption/ desorption characteristics in relation to soil moisture, and adsorption/desorption balance were found to be affected by physicochemical characteristics of each chemical and soil characteristic. Some laboratory ${ }^{5)}$ and field studies $^{8)}$ sought to clarify the relationship between the herbicide in soil solution and its efficacy, however, only limited information is still available to apply their relationship to practical weed control. Our previous field studies on pendimethalin ( $N$-(1-ethylpropyl)2,6-dinitro-3, 4-xylidine $)^{11)}$ and metolachlor (2-chloro-2'-ethyl- $N$-(2-methoxy-1-methylethyl)-6'-methylacetanilide) ${ }^{12)}$ using water extraction method suggested that the herbicidal activity in an upland condition was closely related to water-soluble ingredients, but not to water-insoluble or acetone-soluble ingredients. $\mathrm{We}^{4,7)}$ also found that the herbicidal activity and the mobility of soilapplied thenylchlor (2-chloro- $N$-(3-methoxy2-thienylmethyl)-2', 6'-dimethylacetanilide) was dominated by its concentration in soil solution, which depended on the adsorption/ desorption balance, by introducing a double centrifugation tube to separate the soil solution $^{9)}$. These studies, however, were conducted only under water saturated conditions and the herbicide was incorporated into 
soil in vitro.

Thiobencarb, S-(4-chlorobenzyl) diethylthiocarbamate, is widely used in paddy and upland fields in Japan as a pre-emergence soil-applied herbicide against annual monocotyledonous and dicotyledonous weeds. The objective of this work was to elucidate the dissipation of thiobencarb in soil solution under an upland field condition in relation to its herbicidal activity; laboratory studies were conducted to analyze above relationship in detail.

\section{Materials and Methods}

\section{Field study}

The trial was conducted during 1994 in an upland field of the National Agricultural Research Center (Kannondai, Tsukuba, lightcolored andosol, total carbon: $3.29 \%$, total nitrogen : $0.29 \%$, phosphate adsorption coefficient : 2,241 , cation exchange capacity : $19.0 \mathrm{me} / 100 \mathrm{~g}$, clay content : $12.0 \%)$. Sorghum (Sorghum bicolor), which is relatively sensitive to thiobencarb and selected as an indicator plant for this study, was sowed in 50 $\mathrm{cm}$ long rows $5 \mathrm{~cm}$ apart, at a depth of $3 \mathrm{~cm}$ on May 20th, 1994. On the same day, an emulsifiable concentrate of thiobencarb, $S$ (4-chlorobenzyl) diethyl-thiocarbamate (active ingredient: $50 \%$, Saturn ${ }^{\circledR}$ ), was applied at 5 and $15 \mathrm{~kg}$ a.i./ha with a $\mathrm{CO}_{2}{ }^{-}$ pressurized boom sprayer $\left(3 \mathrm{~kg} / \mathrm{cm}^{2}\right.$, flat fan nozzle, spray volume: $100 \mathrm{ml} / \mathrm{m}^{2}$ ). Soil was sampled at $0-5 \mathrm{~cm}$ depth at $0,3,5,7,11,20,32$, 46 and 62 days after application, and stored in a deep freezer $\left(-20^{\circ} \mathrm{C}\right)$ immediately after sampling until further analysis.

Sorghum growth was also periodically evaluated on plant height, top fresh weight, emergence rate and leaf development. Each treatment was conducted in six replications.

\section{Extraction and determination of thioben-} carb

The sampled soil was divided into soil solution and centrifuged soil by centrifugation with stainless double tubes as described ${ }^{4)}$ Thiobencarb in the soil solution and the centrifuged soil was extracted and prepared for further analysis by a method similar to that used for thenylchlor ${ }^{4)}$. The amount of thiobencarb in the prepared solution was determined by gas chromatography (HP5890) with NP-FID using a glass column packed with $2 \%$ OV-101 on $100-120$ mesh chromosorb $\mathrm{W}$ operating at $200^{\circ} \mathrm{C}$. The carrier gas was nitrogen, air and hydrogen at $25,100,3.5 \mathrm{ml} / \mathrm{min}$, respectively. The detector and injection port was held at 300 and $280^{\circ} \mathrm{C}$, respectively. The detectable limit of thiobencarb was $0.05 \mathrm{ppm}$ and recoveries from the centrifuged-soil and soil solution exceeded $90 \%$.

Thiobencarb distribution in soil layer in laboratory study

Since thin layer soil sampling was difficult in the field trial, the vertical distribution of thiobencarb at application was simulated in a greenhouse. Four plastic rings $(10 \mathrm{~cm}$ in diameter, $1 \mathrm{~cm}$ of high) were piled up and fastened with Parafilm ${ }^{\circledR}$ (American National Can). The moisture of air-dried Kannondai soil was adjusted by distilled water to about $33 \%$ (liquid/total, w/w). The soil was then placed in the rings and put in the greenhouse at 25 to $28^{\circ} \mathrm{C}$. The soil layers were separated 3 hours after thiobencarb spraying at $5,15 \mathrm{~kg}$ a.i./ha with the same spray equipment as used in the field study. Thiobencarb was extracted from each soil layer, and the amount was determined as described above.

Sorghum sensitivity to thiobencarb with water culture

Ten $g$ of sea sand (20-35 mesh) was put into glass vials ( $25 \mathrm{~mm}$ diameter, $70 \mathrm{~mm}$ high), and 

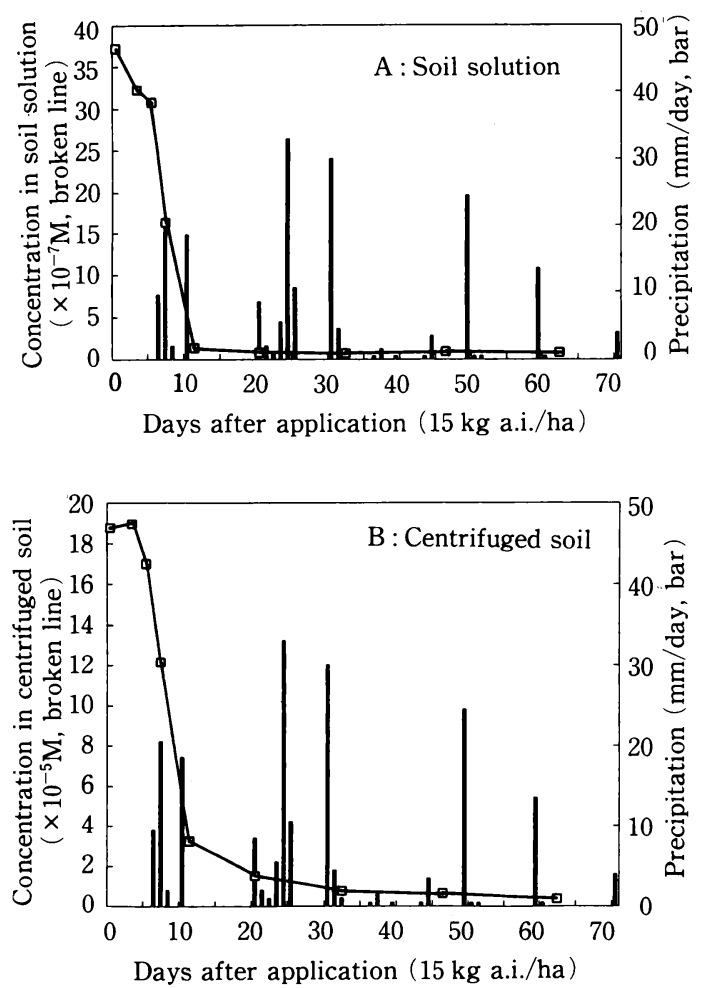

Fig. 1. Changes in thiobencarb concentration in soil solution and centrifuged soil over period of time.

$3.5 \mathrm{ml}$ of thiobencarb solution was applied at a given concentration. Three sorghum seeds were then put onto the sea sand and covered by 8 additional grams of the sand. Shoot length of sorghum was measured 5 days after application.

Each treatment of soil layer and sensitivity was performed with three replicates.

\section{Results and Discussion}

\section{Dissipation of thiobencarb under upland field condition}

The soil moisture (liquid/total, w/w) at sampling was $33.9,33.4,32.0,48.3,41.1,38.7$, $39.8,33.1$, and $33.8 \%$ at $0,3,5,7,11,20,32,46$, and 62 days after application (DAA), respectively, and the precipitation during the trial is shown in Figure 1A, B and Figure 2. In the

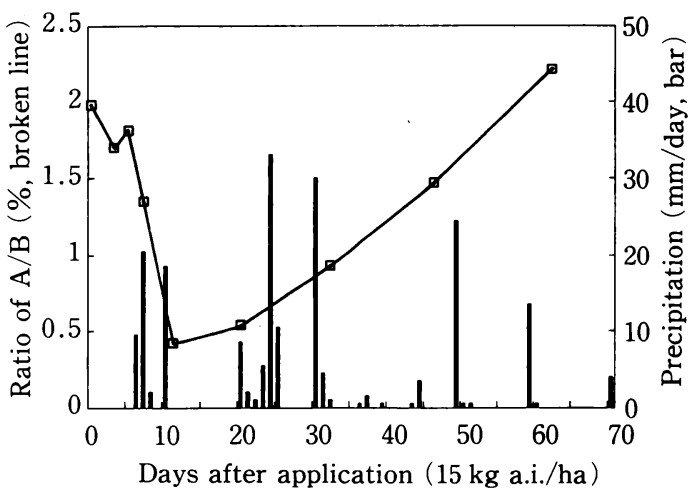

Fig. 2. Change in the ratio of thiobencarb concentration between soil solution (A) and centrifuged soil (B) over period of time.

$0-5 \mathrm{~cm}$ soil sampling at $15 \mathrm{~kg}$ a.i./ha of thiobencarb application, the concentration in the soil solution and the centrifuged soil at application was about $4 \times 10^{-6} \mathrm{M}$ and $2 \times 10^{-4}$ $\mathrm{M}$, respectively (Figure $1 \mathrm{~A}, \mathrm{~B}$ ). Most of the thiobencarb was distributed in the centrifuged soil, and the ratio of thiobencarb concentration between the soil solution and the centrifuged soil was about $2 \%$ at application (Figure 2). The concentration in the solution and the centrifuged soil began to decrease greatly $7 \mathrm{DAA}$, and the concentration at $11 \mathrm{DAA}$ was about $4 \%$ and $17 \%$ of the initial concentration, respectively (Figure 1A, B). The herbicide concentration in soil solution thus decreased with time $e^{1,8,11,12,14)}$. This study supported earlier results, although the chemicals were different from those used in previous studies. The above ratio also decreased to ca. $0.4 \%$ at $11 \mathrm{DAA}$, and then ratio gradually increased to about $2 \%$ at 62 DAA. Decrease in the ratio is assumed to be explained by 1) the high soil adsorption coefficient of thiobencarb, resulting in the decrease of concentration in soil solution as the dissipation of total chemical amount in soil ${ }^{6,13)}$, and 2) herbicide micro-movement into a more adsorptive site or condition in soil, corresponding to a lower concentration 
Table 1. Vertical distribution of thiobencarb in soil just after application.

\begin{tabular}{cccc}
\hline $\begin{array}{c}\text { Thiobencarb } \\
\text { distribution } \\
\text { in soil }\end{array}$ & \multicolumn{2}{c}{ Soil layer Concentration } & $\left(\times 10^{-5} \mathrm{M}\right)$ \\
\cline { 3 - 4 } & $(\mathrm{cm})$ & $5^{*}$ & $15^{*}$ \\
\hline $\begin{array}{c}\text { Soil } \\
\text { solution (A) }\end{array}$ & $0-1$ & 2.4 & 7.3 \\
\hline Centrifuged & $0-2$ & trace & trace \\
soil (B) & $1-2$ & 41.8 & 154 \\
\hline Ratio & $0-1$ & trace & trace \\
(A/B, \%) & $1-2$ & - & 4.7 \\
\hline
\end{tabular}

* : Application dosage (kg a.i./ha)

in soil solution ${ }^{1)}$; the increase tendency at 20 DAA or later, however, could not be explained.

Such changes in time course were also observed when applied at $5 \mathrm{~kg}$ a.i./ha, although the data at $20 \mathrm{DAA}$ and later were below the detectable limit of thiobencarb (data not shown).

\section{Vertical distribution of thiobencarb just after application}

Most of the thiobencarb was distributed in the $0-1 \mathrm{~cm}$ soil surface layer, and the concentration in soil solution $\left(7.3 \times 10^{-5} \mathrm{M}\right)$ was almost 20 times that of the $0-5 \mathrm{~cm}$ soil in the field (Figure 1, Table 1), although the concentration in centrifuged soil was about 8 times that in the field. In general, highly adsorp- tive chemicals were substantially and rapidly adsorbed by the soil, most of them within 1 day, followed by subsequent slow adsorption, which may affect further decrease of the chemical concentration in soil solution ${ }^{1)}$. It is assumed that such a large portion of thiobencarb was distributed in soil solution in $0-1 \mathrm{~cm}$ soil surface at application, because the initial adsorption process was not terminated within 3 hours, and free thiobencarb in the field trial was diluted and adsorbed to other soil particles in deeper layers by mixing.

Sorghum response to thiobencarb in soil in the field and in water culture

Sorghum growth was suppressed in the field applied with thiobencarb at 5 or $15 \mathrm{~kg}$ a.i./ ha within 2 weeks, and then recovered gradually in respect to plant height, top fresh weight, and leaf development (Table 2). In the laboratory, a $50 \%$ and an $80 \%$ inhibitory dose of thiobencarb was $1 \times 10^{-5} \mathrm{M}$ and $8 \times$ $10^{-5} \mathrm{M}$ in water culture, respectively (Figure 3 ), approximately identical with the initial concentration in the soil solution $0-1 \mathrm{~cm}$ from the soil surface $\left(7.3 \times 10^{-5} \mathrm{M}\right)$.

Consequently, it was supposed that the effect of thiobencarb on sorghum was largely dominated by the initial concentration of the

Table 2. Effect of thiobencarb on sorghum growth in upland field condition.

\begin{tabular}{|c|c|c|c|c|c|c|c|c|c|c|c|c|c|c|c|c|c|}
\hline & \multirow{2}{*}{$\begin{array}{c}\text { Dosage } \\
\text { (kg a.i./ha) }\end{array}$} & \multicolumn{4}{|c|}{$\begin{array}{l}\text { Plant height } \\
(\mathrm{mm})\end{array}$} & \multicolumn{4}{|c|}{$\begin{array}{c}\mathrm{TFW}^{*} / \mathrm{plot} \\
(\mathrm{g})\end{array}$} & \multicolumn{4}{|c|}{$\begin{array}{c}\text { TFW/plant } \\
\text { (mg) }\end{array}$} & \multicolumn{2}{|c|}{ Leaf stage } & \multicolumn{2}{|c|}{$\begin{array}{l}\text { Emergence } \\
\text { rate }(\%)\end{array}$} \\
\hline & & 14 & 28 & 46 & 61 & 14 & 28 & 46 & 61 & 14 & 28 & 46 & 61 & 14 & 28 & 14 & 28 \\
\hline \multirow{3}{*}{$\begin{array}{c}\text { Growth } \\
\text { rate } \\
(/ \text { day })^{* *}\end{array}$} & 0 & 3.6 & 5.3 & 19.2 & 51.2 & 0.2 & 0.4 & 8.7 & 76.4 & 8.9 & 20 & 496 & 4803 & 0.15 & 1.8 & 1.4 & -0.2 \\
\hline & 5 & 2.3 & 4.4 & 14.9 & 53.8 & 0.1 & 0.2 & 6.7 & 66.2 & 7.2 & 11 & 462 & 5035 & 0.15 & 0.20 & 1.0 & -0.2 \\
\hline & 15 & 1.4 & 1.6 & 8.6 & 45.3 & 0.1 & 0.0 & 2.6 & 32.9 & 5.3 & 7 & 288 & 3085 & 0.10 & 0.18 & 0.6 & -0.4 \\
\hline \multirow{2}{*}{$\begin{array}{c}\text { Inhibition } \\
(\%)\end{array}$} & 5 & 36 & 25 & 23 & 6 & 27 & 50 & 25 & 15 & 20 & 39 & 8 & -3 & 2 & -3 & 30 & 37 \\
\hline & 15 & 60 & 66 & 65 & 36 & 45 & 78 & 77 & 62 & 41 & 58 & 55 & 42 & 31 & 14 & 56 & 79 \\
\hline
\end{tabular}

* : TFW $=$ Top Fresh Weight

**: The growth response was calculated as follows (" $n$ " means number of evaluation timings) : [evaluation data $(n)-$ evaluation data $(n-1)]$ /interval between $n$ and $n-1$ (days) 


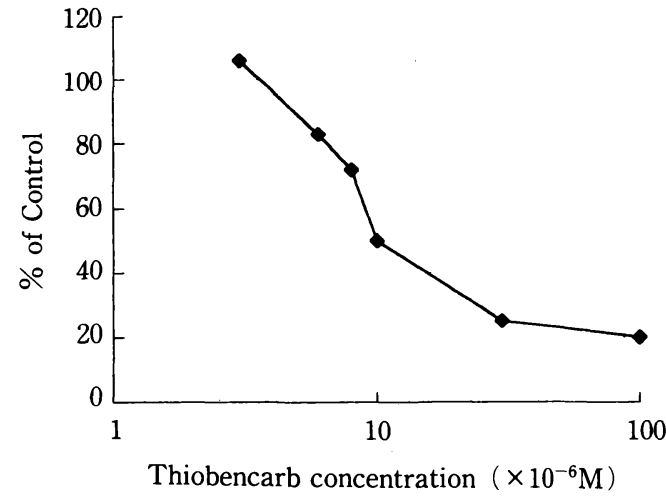

Fig. 3. Sensitivity of sorghum to thiobencarb in water culture.

herbicide in soil solution in the surface soil under an upland condition. This study confirms that the herbicide concentration in soil solution can be a more precise indicator of herbicide efficacy than total herbicide amount in soil, although further studies are needed to apply this to practical weed control, especially as it relates to soil sampling in the field, different soil types/conditions, and different chemicals under field conditions.

Acknowledgements : The authors are grateful to Kumiai Chemical Co. Ltd. for providing Saturn ${ }^{\circledR}$ emulsifiable concentrate and thiobencarb technical.

\section{References}

1) Gaillardon, P., F. Fauconnet, P. Jamet, G. Soulas and R. Calvet 1991. Study of diuron in soil solution by means of a novel simple technique using glass microfibre filters. Weed Res. 31, 357-366.

2) Goetz, A.J., G. Wehtje, R.H. Walker and B. Harjek 1986. Soil solution and mobility characterization of imazaqin. Weed Sci. 34, 788793.

3) Green, R.E. and S.R. Obien 1969. Herbicide equilibrium in soil in relation to soil water content. Weed Sci. 17, 514-519.

4) Kobayashi, K., M. Onoe and H. Sugiyama 1994. Thenylchlor concentration in soil water and its herbicidal activity. Weed Res., Japan 39, 160-164.

5) Lambert, S.M. 1966. The influence of soilmoisture content on herbicidal response. Weeds 14, 273-275.

6) Malik, N. and D.S.H. Drennan 1989. Adsorption-desorption equibria of ${ }^{14} \mathrm{C}$-fluridone at low solution concentrations and soil: water ratios. Can. J. Soil Sci. 69, 567-577.

7) Onoe M., D.J. Lee, K. Kobayashi and H. Sugiyama 1995. Herbicidal activity of soilapplied thenylchlor and its mobility in two paddy soils. Weed Res., Japan 40, 75-79.

8) Patterson, M.G., G.A. Buchanan, R.H. Warker and R.M. Patterson 1982. Fluometoron in soil solution as an indicator of its efficacy in three soils. Weed Sci. 30, 688-691.

9) Seto, M. 1980. Rate of $\mathrm{CO}_{2}$ evolution from soil in relation to content of soil water and amount of dissolved organic carbon in soil solution. Japanese J. Ecol. 30, 385-391.

10) Smith, C.N. and R.F. Carsel 1986. A stainless-steel soil solution sampler for monitoring pesticides in the vadose zone. Soil Sci. Soc. Am. J. 50, 263-265.

11) Sugiyama H., K. Komamiya and K. Kobayashi 1990. Changes in the concentration of residues of pendimethalin applied to soil and effect on plant growth (in Japanese with English Summary). Weed Res., Japan 35, 122-128.

12) Sugiyama H. and K. Kobayashi 1993. Herbicidal activity and residual states of metolachlor in upland soil. Weed Res., Japan 38, 300-306.

13) Streibig, J.C. 1982. Relationship between soil-applied pyrazon and content in soil solution. Weed Sci. 30, 527-531.

14) Wolt, J.D., G.N. Rhodes, J.G. Graveel, E.M. Glosauer, M.K. Amin and P.L. Church 1989. Activity of lazaquin in soil solution as affected by incorporated wheat (Triticum aestivum) Straw. Weed Sci. 37, 254-258. 


\section{畑固場におけるチオベンカーフの土滾溶液中濃} 度の消長と殺草活性

與語靖洋**李 度鎮**・小林勝一郎***杉山 浩*

\section{摘要}

畑粗場におけるチオベンカーブの土壌中の消長 について，二重遠心管を用いた遠心分離法により， 土壤溶液および遠心残查土（遠心土）に分け，存在 形態の経時的変化および殺草活性との関連性につ いて検討した。チオベンカーブ (50\% 乳剤) $15 \mathrm{~kg}$ a.i./ ha 処理において, 本剤の大半が遠心土中に存 在しており (Fig. 1), 両者の分配比 (土壌溶液中濃 度/遠心土中濃度）は処理当日においては約 $2 \%$ で あった。土壌溶液および遠心土中濃度は, 処理 7 日 後から急激に減少し始め, その後さらに減少した。 また分配比は, 処理 7 日後から減少し始めたもの

* 農業研究センター

** 筑波大学応用生物化学系
の, 処理 20 日後から処理時程度まで増加した(Fig 2)。室内実験では, 散布処理したチオベンカーブは, 土壤表層 $1 \mathrm{~cm}$ 以内にそのほとんどが分布し, 土壤 溶液中濃度は圈場試験において $5 \mathrm{~cm}$ 深で採取した 場合に比べ，20 倍近くであった（Table 1)。一方, チオベンカーブのソルガムに対する影響について は, 処理後 2 週間以内に全ての調査項目において生 育阻害が観察されたが，その後生存個体では，葉齢 に続いて草丈・新鮮重が回復したことから，処理後 2 週間以内の作用がその後の生育に強く影響してい ることが明らかとなった(Table 2)。水耕法でのソル ガムのチオベンカーブ感受性の結果 (Fig. 3) も合せ て考えると, 土墡表層 $(1 \mathrm{~cm}$ 以内）における処理 1

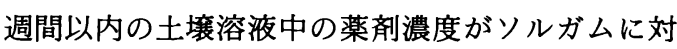
する生育抑制効果に大きく関与していると推測さ れる。

キーワード : チオベンカーブ, 土壌溶液, 畑圃場, 殺 草活性 